\title{
Relationship Between Knowledge and Sme Entrepreneurs' Success in Melaka
}

Maryam Mohd Esa, Noorizda Emellia Mohd Aziz, Muhammad Yasin Omar Mokhtar \& Nor Ainee Idris

To Link this Article: http://dx.doi.org/10.6007/IJARBSS/v11-i2/8859

DOI:10.6007/IJARBSS/v11-i2/8859

Received: 28 December 2020, Revised: 26 January 2021, Accepted: 12 February 2021

Published Online: 28 February 2021

In-Text Citation: (Esa et al., 2021)

To Cite this Article: Esa, M. M., Aziz, N. E. M., Mokhtar, M. Y. O., \& Idris, N. A. (2021). Relationship Between Knowledge and Sme Entrepreneurs' Success in Melaka. International Journal of Academic Research in Business and Social Sciences, 11(2), 461-471.

\section{Copyright: (c) 2021 The Author(s)}

Published by Human Resource Management Academic Research Society (www.hrmars.com)

This article is published under the Creative Commons Attribution (CC BY 4.0) license. Anyone may reproduce, distribute, translate and create derivative works of this article (for both commercial and non-commercial purposes), subject to full attribution to the original publication and authors. The full terms of this license may be seen at: http://creativecommons.org/licences/by/4.0/legalcode

Vol. 11, No. 2, 2021, Pg. 461 - 471

Full Terms \& Conditions of access and use can be found at http://hrmars.com/index.php/pages/detail/publication-ethics 


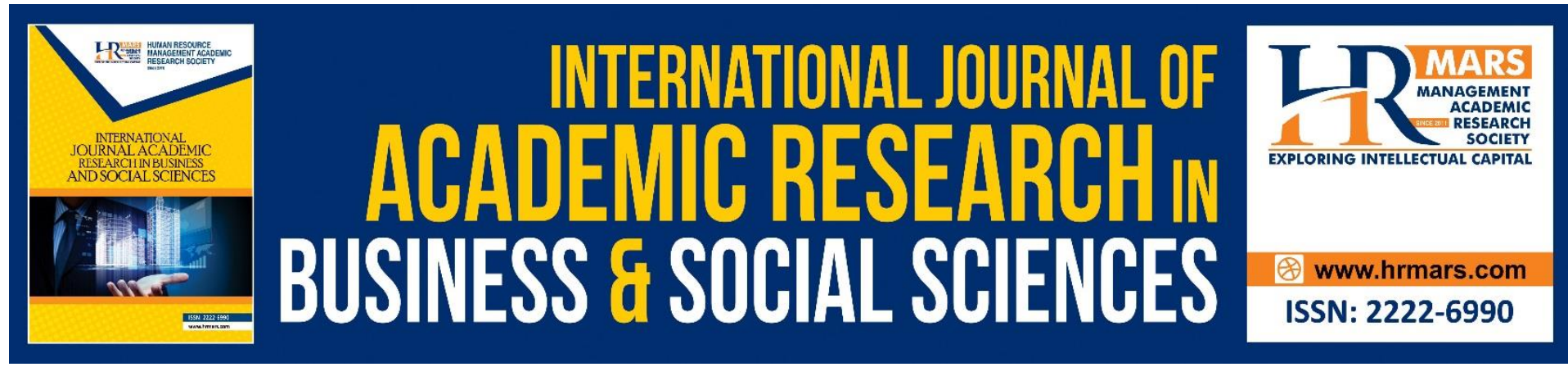

\title{
Relationship Between Knowledge and Sme Entrepreneurs' Success in Melaka
}

\author{
${ }^{1}$ Maryam Mohd Esa, ${ }^{2}$ Noorizda Emellia Mohd Aziz, \\ ${ }^{3}$ Muhammad Yasin Omar Mokhtar \& ${ }^{4}$ Nor Ainee Idris \\ 1 \& 2 Faculty of Innovation \& Technology, Kolej Universiti Islam Melaka, ${ }^{3}$ Research \\ management Centre (RMC), Kolej Universiti Islam Melaka, ${ }^{4}$ Faculty of Languages \& \\ Education, Kolej Universiti Islam Melaka, Malaysia
}

\begin{abstract}
In accordance with Malaysia's aim in becoming an Entrepreneurship Country in line with National Entrepreneurship Policy (DKN 2030), which was officiated in September 2019, the vitality of the industry will be emphasized through small and medium-sized enterprises (SME) activities. Past researches have shown there are relationships between knowledge and entrepreneurs' success. Knowledge is a factor to the entrepreneurship purpose. Therefore, this article discusses the relationship between knowledge and SME's entrepreneurial success in Melaka. Moreover, the existence of various SMEs truly make an impact on a country's economy. The objective of this research is to see the level of knowledge and success of SME entrepreneurs in Melaka and to see the relationship between knowledge and success of SME entrepreneurs in Melaka. This research involved 74 respondents among Malay SME entrepreneurs in Melaka. The findings of this research through descriptive analysis found that the level of knowledge and the factor of respondents' success is at a high level. However, findings through inferential analysis of research hypothesis tests showed a high positive relationship between knowledge and entrepreneurs' success factors. Thus, there are several propositions that can be improved and suggested to the entrepreneurs in particular, an entrepreneur should improve his knowledge about the business he does either new or existing knowledge. Own experience or other people are also a knowledge for an SME entrepreneur to succeed. Finally, other suggestions will be discussed clearly in the research as findings.
\end{abstract}

Keywords: Knowledge, Factors of Success for Entrepreneurs \& Small and Medium-sized Enterprises (SME)

\section{Introduction}

The fifth from six strategic foundations in NEP 2030, is to enforce the ability and performance of small, micro and medium-sized enterprises (Medac, 2019). SME is divided into three; micro, small and medium-sized which is determined through sales turnover and the amount of workers. SME is the key in making entrepreneurship a stepping stone in enhancing economic development that contributes to GDP, thus stimulating the country's investment and export as well as generating job opportunities. However, the ever challenging external environment 
requires entrepreneurs to build resilient strategies in their companies so they can be competitive and continue to survive in their businesses. Direct and indirect knowledge gives an impact to the success of an entrepreneur. According to Zurinah et al. (2019), in Malaysia, the government and private sectors play important roles in gaining the interest of the society in taking on the SME especially those who live in the sub urbans. In addition, she says that a successful entrepreneur does not only create new job opportunities but also enhances job opportunities that focus on the source of new findings, new technology and innovation.

In developing the SME sector and entrepreneurial activities in the rural areas, the government of Malaysia has given a full attention by involving various ministries and institutions for example the Ministry of Entrepreneur Development, the Ministry of Rural and Regional Development, the Ministry of Women, Family and Community Development with the cooperation of Majlis Amanah Rakyat (MARA) (Ayob et. al., 2019), Amanah Ikhtiar Malaysia (AIM), SME Bank, Tabung Ekonomi Usaha Niaga (TEKUN), UDA Holdings Bhd, Bank Pembangunan, Perbadanan Nasional Berhad (PNB), Bank Rakyat, Jabatan Pembangunan Koperasi (JPK), Maktab Kerjasama Malaysia (MKM) and Syarikat Pembangunan Ekonomi Negeri (SEDCs) (Mohamad et. al., 2017). Thus, this research has come up with two (2) main objectives:

- $\quad$ To see the level of knowledge and the level of success of the SME entrepreneurs in Melaka.

- $\quad$ To see the relationship between Melaka SME entrepreneurs' knowledge and success.

\section{Problem Statement}

The main problem statement in this research is the working sector such as the servicing sector that is being offered to the society which has a high income in comparison to the entrepreneurial sector. This is due to the SME sector is still incapable of being competitive globally and the Malay entrepreneurs do not have the high entrepreneurial skills in their businesses. This has resulted in the low involvement of the Malay entrepreneurs. Besides that, there are SME entrepreneurs who do not do market research beforehand in doing their business that lead to constraints in making the SME sector a success. According to SME Corporation (2014), there are several SME entrepreneurs who depend on others thus, giving problems in advancing entrepreneurship.

Although SME is seen as being able to bring positive impact, it has not been able to be competitive in the global market (Nasir, 2017). The SME itself is seen as having some weaknesses such as infrastructures, operation, management and others. Despite billions of ringgit being spent by the government in supporting the SME through various incentives, the failure rate is still high (Ahmad, 2007).

Empirical findings revealed that strategic management is less applied (Wagner, 2010) and less popular in the SME due to lack of knowledge about the processes and expertise in the management (Gibbon and O'Connor, 2005). Thus, Gunther, Menzel and Jentsch (2011) said that most SME focused on daily businesses or short term operational activities where business development itself is not sufficient without taking the long term perspective into account. 
Most SMEs which do not perform are because they prioritize short term profit ie, they do not consider data collection in comparison to practicing strategic, significant management with long term profit stated by Turgay and Kassegn, 2005 (Hoetoro, 2020). In addition, Wang et. al. (2011) emphasized that strategic management is the main ingredient for the development, competitiveness, success, and SMEs' achievement.

Wood and Joyce (2003) outlined that entrepreneurs who practice strategic management are decisive, and successful in making changes and innovations in gaining SMEs' achievement. From the perspective of the entrepreneur himself, it is predictable that the factors that contribute to the failure of an entrepreneur in continuing his business are their lack of knowledge in entrepreneurship foundation. Some venture into this field without knowledge, skill and sufficient training in conducting business well.

\section{Literature Review}

The Success of Malay SME Entrepreneurs

The Small and Medium-Sized Enterprises (SMEs) is a term that has many interpretations according to specific aspects of a business such as sales, capital, the size of fixed assets, amount of work hired, output value and others. The measurement and assessment of SMEs of a country differs from one another in terms of size and criteria. SME Corp Malaysia (2014) defined the success of SME Malay entrepreneurs refers to Malay business which is also classified as one of two qualified criteria i.e., annual sales or the number of full time workers as well as any one that is low. Furthermore, Sarimah (2013) recognised that the term 'entrepreneur' originated from French 'entreprendre' meaning to undertake a task or responsibility and stated Richard Cantillon (1775), who was a pioneer in entrepreneurship said that an entrepreneur is a person who takes risks and he is different from a person who provides capital. Alauddin (2014) said that the success of Malay entrepreneurs depends on the ability of an individual in a business that he ventures into. Hashim, Norasmah \& Noraishah (2009), said that management and marketing aspects are important for entrepreneurs' success. The criteria of successful entrepreneurs are those who are not intimidated by opponents' strengths by making them as advantages to compete. They have to start by not being dependent solely on a given opportunity. Successful entrepreneurs must act fast to change strategies being executed according to current needs. This means they do not rely only on the tenacity of initial strategy. Preferably, strategy will be changed whenever in need. Next, they are wise in utilizing time according to Timmons and Spinelli (2009). The main criteria is they have the attitude of doing something that the unsuccessful people 'do not like' and 'will not do' according to Megginson et al (2001).

Moreover, according to Timmons and Spinelli (2009), successful entrepreneurs must act fast to change the strategy that they do according to current needs. The real success of entrepreneurs depend on their own efforts, skills and initiatives in grabbing the chance and space despite various supports from government as told by Datuk Seri Ahmad Maslan in determining the reasons behind the lacking of Malays and Bumiputra becoming entrepreneurs and measures in multiplying them during a verbal QA session in Dewan Rakyat.

The English word 'entrepreneur' originated from French 'entreprendre' meaning to undertake a task or responsibility. An entrepreneur is an individual who runs a business whereas a businessman is a person who does business. Generally, an entrepreneur can be 
defined as a person who runs a business successfully with the motive of gaining profit as well as practicing strategic practices to continue to succeed according to Azrain (2010).

Next, the government has aimed at the contribution of small and medium-sized enterprises (SME) to Gross Domestic Product (GDP) to increase to 42 percent in the next one year in comparison to 37 percent in present. According to the Medac (2019) stated by Mohd Redzuan Yusof said the target is achievable although the proposed numbers are unfavourable at present but it is doable if the entrepreneurs make adequate preparation including facing the fourth Industrial Revolution (IR 4.0) challenges.

\section{Knowledge Factors}

Malaysia is pursuing becoming an Entrepreneurial Nation through the National Entrepreneurship Policy (NEP) 2030 (Medac, 2019). Therefore, multiple parties try to improve this field through numerous strategies and methods. Knowledge in entrepreneurship is important in line with the development of national entrepreneurial education which is practiced in all education levels; elementary, intermediate and tertiary and higher learning institutions as well as experience as part of gaining entrepreneurial-related knowledge. The factors being studied are said to propel an SME to be sustainable and successful. Knowledge in business is vital besides possessing experience. Thus, businessmen can enroll in courses offered by the government and private sectors through seminars, talks and entrepreneurial conventions held by certain parties. This can assist businessmen to gain information about business opportunities around them. Fierce competition shows the importance of an entrepreneur to prepare himself with adequate knowledge so the Malay entrepreneurs can compete with other entrepreneurs from different races.

Due to the fact, in relation to the factor of knowledge possessed by entrepreneurs studied by Azmi, AC. et al. (2012), the researchers find that the success of an SME starts with knowledge; knowledge about entrepreneurship and the interest to venture into business. Knowledge and skills as mentioned are the skill to plan, the skill to manage an organization as well as past experience about the business. According to Buerah and Hussin (2014), the success of a business also starts with knowledge which is the formal and informal learning and skills. For example, Malay entrepreneurs who lack skills in business and lack of knowledge about the method in running a business. Knowledge means facts, feelings or past experience of an individual in life. According to Zanariah et al. (2014), knowledge is the basic thing towards the achievement of a person because it is the point to drive someone to make a decision. Therefore, every entrepreneur has to know the way to advance his SME business by gaining lucrative results.

Furthermore, the point to drive someone to make a decision is knowledge which is the basic thing towards the achievement of a person because it is. Therefore, every entrepreneur has to know the way to advance his SME business by gaining lucrative results. When a person chooses to be an entrepreneur, he has to prepare himself with the basic knowledge in business and the easiest example is financial management. Knowledge in entrepreneurship must be emphasized because history has made entrepreneurs fail due to lack of knowledge in business, particularly the basics such as managing profit and determining the volume of stocks to buy. 
By far, most studies particularly foreign studies, associate knowledge and entrepreneurship with the development of business such as the study by Audretsh and Lehman (2004), Acs, Audretsh, Braunerhjelm, and Carlsson (2005), Thomas (2003) and many more. Several local researchers have associated education aspect and knowledge with the success of an entrepreneur. Among them are Norasmah \& Halimah (2007) and others.

The main results from this article about the education of entrepreneurship is there are still room for research opportunities that have not been found. The entrepreneurial education researchers have to continue to search for the innovative teaching method and to develop the skill of critical thinking. The researchers admit that interest in the future research is subjective and mostly determined by the attitude of the researchers towards the topic. In order to increase our understanding about the processes that lead to the success of entrepreneurial results from education courses, mutual consensus about the result of something is needed. This includes the delivery towards students about the benefit of entrepreneurial education and there is also time to look at the result of taking a course. The main learning objectives must be made into the entrepreneurial education curriculum in optimizing students' participation. There are researches that predict future learning scenarios for entrepreneurial education and how to increase learning effectiveness. The researchers are very enthusiastic about the new teaching method that has potential in entrepreneurial education in assessing how critical thinking enhances learning outcomes.

\section{Methodology}

This study involved 74 SME Malay respondents in Melaka. The researchers have focused on Malays who wanted to be entrepreneurs and started business. The method is by using Tabachnick and Fidell Technic (2013), which is simple random sampling whereby all SME Malay entrepreneurs have more opportunities to be chosen as samples.

$$
\begin{gathered}
N^{>>} 50+8(\mathrm{~m}) \\
\mathrm{N}=\text { sample } \\
\mathrm{M}=\text { number of variables } \\
N^{>>} 50+8(3)=74 \text { respondents }
\end{gathered}
$$

Therefore, overall, the researchers chose 74 respondents from random groups in this research. The instrument used and item numbers that are in every questionnaire is mentioned in the table below.

Table 2.0: Research instrument

\begin{tabular}{|l|c|}
\hline Aspects & Number of Questions \\
\hline $\begin{array}{l}\text { The success of SME Malay Entrepreneurs } \\
\text { (SME Corp. Malaysia 2014) }\end{array}$ & 5 \\
\hline $\begin{array}{l}\text { Knowledge (Yusrina, Nurhanita \& Nurul } \\
\text { Huda, 2018) }\end{array}$ & 5 \\
\hline
\end{tabular}




\section{Findings}

Descriptive Analysis

Min Level Analysis

The analysis in this section aims to address the research objectives outlined in the previous chapter. The analysis was performed using a descriptive analysis method. Using this method, relevant data such as mean and standard deviation will be released.

Table 3.1: Interpretation of mean Score (Davis, 1971)

\begin{tabular}{|c|c|}
\hline Statement & Score \\
\hline High & $3.68-5.00$ \\
\hline Moderate & $2.34-3.67$ \\
\hline Low & $1.00-2.33$ \\
\hline
\end{tabular}

Table 3.2: Min Level Variable Analysis

\begin{tabular}{|c|c|c|}
\hline Variable & & \\
\hline & Min & Std. deviation \\
\hline Knowledge & 4.311 & 0.425 \\
\hline Entrepreneurs' Success & 4.138 & 0.481 \\
\hline
\end{tabular}

The analysis in the table shows the variable of knowledge showing $\min =4.311$, standard deviation $=0.425$. However, the variable of entrepreneurs' success shows $\min =4.311$, standard deviation $=0.481$. The findings for descriptive analysis can be concluded that according to data interpretation min Davis (1971), both variables are at a high level.

\section{Inference Analysis}

Hypothesis: there is a significant relationship between knowledge and entrepreneurs' success in Melaka.

Table 3.3: Result of knowledge correlation with entrepreneurs' success in Melaka.

\begin{tabular}{|c|c|}
\hline Variable & Entrepreneurs' Success \\
\hline Knowledge & $.529^{* *}$ \\
\hline
\end{tabular}

\footnotetext{
** significance is at level $0.01(2)$
}

Result from correlation analysis between knowledge and entrepreneurs' success shows the value $r=.519$ whereas value $p<0.05$. This shows a significant relationship between knowledge and entrepreneurs' success. The correlation relationship is at a high level. Therefore the hypothesis is accepted.

\section{Discussions}

Based on the research, the researchers found that knowledge has a high correlation with the SME entrepreneurs' success factors in Melaka. In addition, the interpretation of data mean Davis (1971), says that both variables are at a high level. 
The findings from the analysis showed that entrepreneurs' success is based on knowledge of an individual. This finding is supported by past research by Manaf (2012), saying that the success of an SME starts with knowledge i.e, learning or skills acquired formally or informally. Knowledge and skills as mentioned such as skill in planning, skill in managing organization and past experience related to business undertaken. This research finding is also supported by research by Audretsh and Lehman (2004), Acs, Audretsh, Braunerhjelm, and Carlsson (2005), Thomas (2003) and Norasmah \& Halimah (2007). It is undeniable that sufficient knowledge is important because in becoming a successful entrepreneur, adequate preparation is vital in overcoming obstacles.

According to Zanariah et al. (2014), knowledge is the basic element to every achievement because it is the factor to push someone to make a decision. Therefore, every entrepreneur should know the method to push forward their own enterprise in gaining high profit. If all entrepreneurs in Melaka can develop by using experience equipped with training exposure and proper knowledge, it is not impossible that all SME areas flourish and help in boosting the economy in Melaka.

\section{Conclusion}

Based on the research done, there are several improvements that can be made and suggested to the entrepreneurs. As an entrepreneur, they have to increase knowledge about the business that they are doing be it a new or existing business. As an example, an entrepreneur has to equip himself with various entrepreneurial skills including skill in communication. An entrepreneur is also suggested to gain information on how to start a business by using accurate strategy. In addition, an entrepreneur should also emphasize on exchanging ideas among themselves in expanding their businesses by getting business consultation from successful and experienced entrepreneurs in understanding the rise and fall of a business. On top of that, an entrepreneur also should increase his knowledge in marketing by attending seminars, entrepreneurial programs as well as the development of experienced entrepreneurs through accountable government agencies. Entrepreneurs should attend entrepreneurial training and workshops in acquiring business skills and opportunities easily. Other than that, the government plays an important role in helping entrepreneurs to achieve success by providing classes to market their products in foreign markets and strengthening their skills in business. This helps the manager to manage the situation rationally due to changes in the surrounding. In addition, entrepreneurs have to analyse the benefits from business opportunities that have been identified to always seize prospects prepared by stakeholders and existing agencies to enhance the abilities of the entrepreneurs in keeping them sustainable and successful in advancing their business in the future. Finally, the researchers see that this research can be explained and developed by analysing several issues that are not covered in the research. Future researchers are encouraged to increase the number of respondents so as to increase the validity towards the research being studied comprehensively. Besides, future researchers can diversify types of research instruments such as interview method or collaborating interview method with questionnaires by providing open- ended questions to respondents. Therefore, future researchers are expected to review and explain in detail about the successful factors of the Malay SME entrepreneurs in Malaysia. In essence, this paper will become a starting point for researchers to explore more regarding this knowledge and successful concept in entrepreneurship that can bring contribution to the nation in increasing the numbers of successful entrepreneurs who directly impact our 
national income. We believed that, this paper also elaborated on how theoretically similar the concept of knowledge to develop successful entrepreneurs where both knowledge and success have their own level emphasizes on lifelong learning education. That will mix formal and non-formal education as an experience to entrepreneurs to get the knowledge and help significantly in developing individuals as a successful entrepreneur in the future. In addition, naturally we are born as a khalifah that is related to the meaning of entrepreneur from Islamic views. Everybody has a chance to become a successful entrepreneur with the knowledge of entrepreneurship through education timely. This article will become a valuable source of reading materials towards future studies which are more comprehensive by the scholars in this field.

\section{Acknowledgement}

This research is not under specific grant from any funding agency in the public, commercial or not for profit sectors.

\section{Corresponding Author}

Maryam Mohd Esa Kolej Universiti Islam Melaka Malaysia

Email: maryam@kuim.edu.my

\section{References}

Abidin, Z. Z., Abdullah, A., \& Rahim, H. L. (2016). The Relationship of Entrepreneurship Courses, Entrepreneurship Activities, Academic Grades, and Business Creation among Graduates. In Proceedings of the ASEAN Entrepreneurship Conference 2014 (pp. 81-88). Springer, Singapore.

Acs, Z. J., Audretsch, D. B., Braunerhjelm, P., \& Carlsson, B. (2005). Growth and Entrepreneurship: An Empirical Assessment (No. 3205). Papers on Entrepreneurship, Growth and Public Policy.

Ahmad, N. H. (2007). A Cross Cultural Study of Entrepreneurial Competencies and Entrepreneurial Success in SMEs in Australia \& Malaysia. University of Adelaide Australia.

Audretsch, D. B., \& Lehmann, E. E. (2005). The Effects of Experience, Ownership, and Knowledge on IPO Survival: Empirical Evidence from Germany. Review of Accounting and Finance.

Ayob, N. A., Mohamadb, N. H., Zahidc, N., Nadia, N., Hassand, A., \& Rahmane, F. A. A. (2019). Contributing Factors to the Success of Small and Medium Enterprises (SMEs) in Kelantan. International Journal of Innovation, Creativity and Change, 6(3), 176-190.

Azrain, N. M. (2010). Prinsip Asas Keusahawanan.

Buerah, T., \& Hussin, S. (2014). Perubahan Sikap Keusahawanan Usahawan Melayu di Malaysia/Buerah Tunggak, Hussin Salamon. e-BANGI: Jurnal Sains Sosial dan Kemanusiaan, 9(1), 98-116.

Coulson-Thomas, C. (2003). The Knowledge Entrepreneur: How Your Business Can Create, Manage and Profit from Intellectual Capital. Kogan Page Publishers.

Davis, J. A. (1971). Elementary Survey Analysis. USA: Englewood Cliffs, NJ: Prentice-Hall.

Gibbons, P. T., \& O'connor, T. (2019). Influences on Strategic Planning Processes among Irish SMEs. Journal of Small Business Management. Vol 43, 2002-Issue 2.

Günther, L., Menzel, D., \& Jentsch, D. Intervention Method for Participatory Strategy 
Development and Implementation (IPAS)-A Way to Enhance Strategic Thinking and Acting of SMEs. International Journal of Business and Management Studies., 3(1), 215-226.

Hashim, N., Othman, N., \& Buang, N. A. (2009). Konsep Kesediaan Keusahawanan Berdasarkan Kajian Kes Usahawan Industri Kecil dan Sederhana (IKS) di Malaysia (Entreprenuership Readiness Concept Based on Case Study of Small Medium Industry (SMI) Entrepreneurs in Malaysia). Jurnal Pendidikan Malaysia (Malaysian Journal of Education), 34(1), 187-203.

Hoetoro, A. (2020). The Dynamics of Performance Improvement among SMEs Clusters in East Java. In 23rd Asian Forum of Business Education (AFBE 2019) (pp. 291-296). Atlantis Press.

Manaf, A. A., Omar, N. H., \& Yee, L. K. (2012). Faktor Kritikal Kejayaan Usahawan dalam Perniagaan. e-BANGI, 7(1), 34-45.

Megginson, W. L., \& Netter, J. M. (2001). From State to Market: A Survey of Empirical Studies onPrivatization. Journal of Economic Literature, 39(2), 321-389.

Ministry of Entrepreneur Development and Cooperatives (Medac). (2019). National Entrepreneurship Policy 2030. Malaysian: An Outstanding Entrepreneurial Nation 2030. Putrajaya.

Mohamad, Z. U. M. S., Harun Arrosyid, A. N., Moi, M. R., Wan Hassin, W. S., \& Shah Shahar, W. S. (2017). Faktor-faktor yang Mempengaruhi Kejayaan Usahawan Wanita Tekun: Satu Kajian di Daerah Hulu Langat. In Proceeding of the 4th International Conference on Management and Muamalah 2017 (ICoMM 2017) (pp. 398-407). Faculty of Management and Muamalah, Kolej Universiti Islam Antarabangsa Selangor (KUIS).

Nasir, W. M. N. B. W. M., Al Mamun, A., \& Breen, J. (2017). Strategic Orientation and Performance of SMEs in Malaysia. SAGE Open, 7(2), 2158244017712768.

Norasmah, O., \& Halimah, H. (2007). Keusahawanan Remaja Malaysia. Universiti Putra Malaysia.

Sarimah, H. A. S., \& Cecilia, S. T. L. (2013). Entrepreneurship. ( $3^{\text {rd }}$ Ed.) Shah Alam : Oxford Fajar.

Sidal, A. (2014). Taksonomi Keupayaan Usahawan Wanita Melayu (Taxonomy on Malay Women Entrepreneurs Potentials). Journal of Human Capital Development (JHCD), 7(2), 63-78.

SME, Corp. (2014). Garis Panduan: Definisi Baharu PKS SME Corp. Malaysia Sekretariat bagi Majlis Pembangunan PKS. Retrieved http://www.smecorp.gov.my.

Tabachnick, B. G., \& Fidell, L. S. (2013). Using Multivariate Statistics (6 ${ }^{\text {th }}$ ed.) Boston, MA: Pearson.

Tahir, Z., Malek, J. A., Selvadurai, S., \& Hussain, Y. (2019). Transformasi Memajukan Industri Kecil dan Sederhana (IKS) di Kalangan Wanita Luar Bandar (Transformation to Promote Small and Medium Industries (SMIs) among Rural Women). Geografia-Malaysian Journal of Society and Space, 15(4).

Timmons, J. A., Spinelli, S. (2009). New Venture Creation, Entrepreneurship for the $21^{\text {st }}$ Century. (7 Ed.) New York. McGrawHill.

Wagner, R. (2010). The Effects of Management Education upon Strategic Practice and Performance: The Case of the German SME Machinery and Equipment Sector. Faculty of Law, Business \& Social Science. University of Glaslow.

Wang, C., Walker, E., \& Redmond, J. (2007). Explaining the Lack of Strategic Planning in SMEs: The Importance of Owner Motivation.

Woods, A., \& Joyce, P. (2003). Owner-managers and The Practice of Strategic Management. International Small Business Journal, 21(2), 181-195. 
Yusoff, Y. B. H., Husain, N. B. M., \& Yahya, N. H. B. (2018, February). Faktor-Faktor Yang Mempengaruhi Kecendurungan Pelajar Terhadap Pemilihan Produk HALAL Di Malaysia: Kajian Ke Atas Pelajar Muslim Jabatan Perdagangan POLIMAS. In iCompEx18 Pembentangan Kertas Penyelidikan Akademik. 